\title{
Erratum: Tran et al. Early Cellular Responses Induced by Sedimentary Calcite-Processed Particles in Bright Yellow 2 Tobacco Cultured Cells. Int. J. Mol. Sci. 2020, 21, 4279
}

\author{
Daniel Tran ${ }^{1,2, *(\mathbb{D})}$, Tingting Zhao ${ }^{2}$, Delphine Arbelet-Bonnin ${ }^{2,3}$, Takashi Kadono ${ }^{2,4}$, Patrice Meimoun ${ }^{2}$ (D), \\ Sylvie Cangémi ${ }^{2}$, Tomonori Kawano ${ }^{4,5,6,7}$, Rafik Errakhi ${ }^{8}$ and François Bouteau 2,3,5,6
}

check for

updates

Citation: Tran, D.; Zhao, T.;

Arbelet-Bonnin, D.; Kadono, T.;

Meimoun, P.; Cangémi, S.; Kawano,

T.; Errakhi, R.; Bouteau, F. Erratum:

Tran et al. Early Cellular Responses Induced by Sedimentary

Calcite-Processed Particles in Bright

Yellow 2 Tobacco Cultured Cells. Int.

J. Mol. Sci. 2020, 21, 4279. Int. J. Mol.

Sci. 2021, 22, 6863. https://doi.org/

$10.3390 /$ ijms 22136863

Received: 7 June 2021

Accepted: 10 June 2021

Published: 25 June 2021

Publisher's Note: MDPI stays neutral with regard to jurisdictional claims in published maps and institutional affiliations.

Copyright: (c) 2021 by the authors. Licensee MDPI, Basel, Switzerland. This article is an open access article distributed under the terms and conditions of the Creative Commons Attribution (CC BY) license (https:// creativecommons.org/licenses/by/ $4.0 /)$.
Agroscope, Institute for Plant Production Systems, 1964 Conthey, Switzerland

2 Laboratoire Interdisciplinaire des Energies de Demain, Université de Paris, 75013 Paris, France; zhaotingting0325@gmail.com (T.Z.); delphine.bonnin@univ-paris-diderot.fr (D.A.-B.); kadono.takashi@gmail.com (T.K.); patrice.meimoun@upmc.fr (P.M.); sylvie.cangemi@univ-paris-diderot.fr (S.C.); francois.bouteau@univ-paris-diderot.fr (F.B.)

3 Cogitamus Laboratory, 75013 Paris, France

4 Graduate School of Environmental Engineering, University of Kitakyushu, 1-1 Hibikino, Wakamatsu-ku, Kitakyushu 808-0135, Japan; kawanotom@gmail.com

5 LINV Kitakyushu Research Center(LINV@Kitakyushu), Kitakyushu 808-0135, Japan

6 International Photosynthesis Industrialization Research Center, The University of Kitakyushu, Kitakyushu 808-0135, Japan

7 Paris Interdisciplinary Energy Research Institute (PIERI), Université de Paris, 75013 Paris, France

8 Eurofins Agriscience Service, Casablanca 20000, Morocco; r.errakhi@gmail.com

* Correspondence: qnoctnandaniel.tran@agroscope.admin.ch

The authors would like to remove the scientific consortium 'Camille Nous' from the author list and the Author Contributions section in the published paper [1], as suggested by the Editorial Office. To recognize the consortium's contribution, the authors claimed a double affiliation of two of the authors to the Cogitamus laboratory [2]. The original article has been updated.

\section{References}

1. Tran, D.; Zhao, T.; Arbelet-Bonnin, D.; Kadono, T.; Meimoun, P.; Cangémi, S.; Kawano, T.; Errakhi, R.; Bouteau, F. Early Cellular Responses Induced by Sedimentary Calcite-Processed Particles in Bright Yellow 2 Tobacco Cultured Cells. Int. J. Mol. Sci. 2020, 21, 4279. [CrossRef] [PubMed]

2. Cogitamus Laboratory. Available online: https://www.cogitamus.fr/faqen. 